\title{
Eurolntervention
}

\section{Micro-computed tomographic assessment following extremely oversized partial postdilatation of drug-eluting stents}

\author{
Mounir W.Z. Basalus', MD; K. Gert van Houwelingen', MD; Marc J.K. Ankone², Msc; Jan Feijen², \\ Msc, PhD; Clemens von Birgelen ${ }^{1,2 *}, \mathrm{MD}, \mathrm{PhD}$ \\ 1. Department of Cardiology, Thoraxcentrum Twente, Enschede, The Netherlands; 2. MIRA - Institute for Biomedical \\ Technology and Technical Medicine, University of Twente, Enschede, The Netherlands
}

The authors have no conflict of interest to declare.

This paper also includes accompanying moving images published at the following website: www.eurointervention.org

\section{KEYWORDS \\ Drug-eluting stents, micro-computed tomography, percutaneous coronary interventions, oversized postdilation, coronary artery disease, open-cell design, closed-cell design}

\begin{abstract}
Aims: To assess the spatial geometry of drug-eluting stents (DES) following extremely oversized proximal postdilatation. Interventions of distal left main (LM) disease generally require stenting across the LM bifurcation with inherent vessel tapering along this segment and a high likelihood of stent malapposition, which can be avoided by such postdilations.

Methods and results: Sixteen DES (four 3.5 mm-samples of Cypher Select Plus, Taxus Liberté, Endeavor Resolute, Xience V) were deployed in water; 12 samples were then proximally postdilated with noncompliant $5.0 \mathrm{~mm}$ balloons at $18 \mathrm{~atm}$. All samples were examined by micro-computed tomography. Taxus Liberté, Endeavor Resolute, and Xience V, showed increased cell areas in the transitional region (just distal to postdilated region), while Cypher Select showed its largest cells inside the postdilated region. Overall, the largest maximum cell area was observed in Endeavor Resolute, while Cypher Select showed the smallest $(p<0.001$, for both). In addition, the size of the very proximal postdilated cells was relatively small in most DES except Xience $\mathrm{V}$.

Conclusions: Extremely oversized partial stent postdilatation demonstrated significant between-DES differences in final spatial stent configuration and maximum cell size. These data could be of practical interest with regard to coronary interventions in LM stems with stenting across the LM bifurcation.
\end{abstract}

\footnotetext{
* Corresponding author: Thoraxcentrum Twente, Department of Cardiology, Haaksbergerstraat 55, 7513ER Enschede, The Netherlands
} E-mail: c.vonbirgelen@mst.nl 


\section{Abbreviations \\ DES: drug-eluting stent \\ Micro-CT: micro-computed tomography \\ $\mathrm{PCl} \quad$ percutaneous coronary intervention \\ LM: left main}

\section{Introduction}

There is growing evidence that - in case of a favourable anatomy percutaneous coronary interventions $(\mathrm{PCl})$ with drug-eluting stents (DES) may represent a valuable alternative to coronary artery bypass grafting for the treatment of significant left main (LM) coronary artery disease..$^{1,2}$ Recently, it has been suggested that DES use in unprotected left main disease should be considered as Ila recommendation. ${ }^{3}$ Isolated mid LM stenoses can frequently be treated by stenting the left main stem only, while distal LM disease represents a more challenging situation as it requires stenting of the transition between the distal LM stem and a proximal segment of one of the major left coronary branches with inherent major tapering and very substantial differences in lumen size between the distal and proximal part of the coronary segment to be stented. ${ }^{4}$ In this setting, oversized postdilatation of the proximal part of the stent (inside the LM stem) will generally be mandatory to avoid stent malapposition, which could promote DES thrombosis and restenosis. ${ }^{5-8}$ Such partial postdilation often requires significant oversizing of the balloon compared to the nominal diameter of the implanted stent (Figure 1), which may affect the final geometrical stent configuration and the size of stent cells with potential consequences for side branch access. ${ }^{9}$

The response of DES geometry to such extremely oversized postdilatation of the proximal stent segment is greatly unknown. In the present bench side study, we used micro-computed tomography (Micro-CT) to examine this issue in four types of commercially available DES.

\section{Methods}

\section{DES samples examined}

We examined four types of commercially available DES. A total of 16 DES were examined: four Cypher Select Plus ${ }^{\mathrm{TM}}$ (Cordis Europa, Roden, The Netherlands), four Taxus LibertéTM (Boston Scientific Corp., Natick, MA, USA), four Endeavor Resolute ${ }^{\mathrm{TM}}$ (Medtronic Vascular, Santa Rosa, CA, USA), and four XIENCE VTM (Abbott


Figure 1. DES malapposition in the left main stem corrected by extremely oversized partial (proximal) postdilation of the DES. A) Implantation of $3.5 / 32 \mathrm{~mm}$ DES with subsequent postdilation with $4.0 \mathrm{~mm}$ balloon. B) DES malapposition in the LM stem demonstrated by intravascular ultrasound (indicated by dotted gray line). C) Postdilation with $4.5 \mathrm{~mm}$ balloon. D) Persistence of minor malapposition. E) Postdilation with 5.Omm balloon. F) Disappearance of malapposition in the postdilated stent region. 
Vascular, Santa Clara, CA, USA). Stent dimensions were $3.5 \times 23 \mathrm{~mm}$ for Cypher Select and Xience $V$ and $3.5 \times 24 \mathrm{~mm}$ for Endeavor Resolute, and Taxus Liberté.

The Cypher Select is based on a laser-cut stainless steel platform (based on a modification of BX Velocity; strut thickness $140 \mu \mathrm{m}$ with seven links between each two adjacent rings), covered with a primer layer of paralyne $C$ and a main coating layer made of polyethylene-co-vinyl acetate (PEVA) and poly n-butyl methacrylate (PBMA) and sirolimus. ${ }^{10}$

Taxus Liberté is based on a laser-cut, stainless steel stent platform

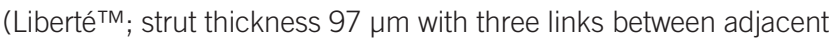
stent rings), coated with a $17.8 \mu \mathrm{m}$-thick layer of SIBS (styrene-bisobutylene-b-styrene) polymer and paclitaxel. ${ }^{11}$

Endeavor Resolute is based on the a cobalt-chromium stent platform (Driver ${ }^{\mathrm{TM}}$; strut thickness $91 \mu \mathrm{m}$ ), which is made of stent rings that are laser-welded at two to three points, the stent is covered by $5.6 \mu \mathrm{m}$-thick (information obtained from manufacturer) biolinx ${ }^{\mathrm{TM}}$ polymer and zotarolimus. ${ }^{12}$

Xience $\mathrm{V}$ is based on a laser-cut, cobalt-chromium stent platform (Vision ${ }^{\mathrm{TM}}$, strut thickness $81 \mu \mathrm{m}$ ) that consists of stent rings that are connected by three multi-links, covered by a $7.8 \mu \mathrm{m}$-thick layer of fluoropolymer and everolimus. ${ }^{13}$

\section{DES expansion protocol}

All stents (sterile packed; expiration date not passed) were expanded at $14 \mathrm{~atm}$ by an interventional cardiologist under sterile conditions in a sterile water bath at $37^{\circ} \mathrm{C}$. Consecutively, the proximal part of 12 DES sample (three of each DES type) were postdilated at $18 \mathrm{~atm}$ with 5.0/12 $\mathrm{mm}$ non-compliant balloon catheters (Quantum Maverick Monorail ${ }^{\circledR}$; Boston Scientific Corp., Natick, MA, USA). Four samples (one sample of each DES type) were not postdilated and were used as control samples. All DES were consecutively dried under laminar air flow. Stent expansion, drying, and examination of the samples were performed at the University of Twente in Enschede at an experimental laboratory with laminar air flow, being almost free from dust. Figure 2 demonstrates the location of the postdilatation balloon (and the balloon markers) in relation to the stent.

\section{Nomenclature of stent regions}

(1) distal "non-postdilated region" subjected to the 14 atm expansion pressure only;

(2) proximal "postdilated region" subjected to both $14 \mathrm{~atm}$ implantation pressure plus postdilatation with a $5.0 / 12 \mathrm{~mm}$ noncompliant balloon at $18 \mathrm{~atm}$;

(3) the "transitional region" between the two aforementioned regions in which the stent diameter showed a gradual decline.

\section{Micro-CT examination}

Four samples of each of the four DES types $(n=16)$ were examined with the Explore Locus SP Micro-CT (GE Healthcare, Milwaukee, WI, USA). The greyscale image data obtained from the Micro-CT scan were thresholded to distinguish between stent voxels and space voxels. The spatial resolution applied was $8 \mu \mathrm{m}$ (voxels being $8 \times 8 \times 8 \mu m^{3}$ volume-elements). Due to the metal nature of the
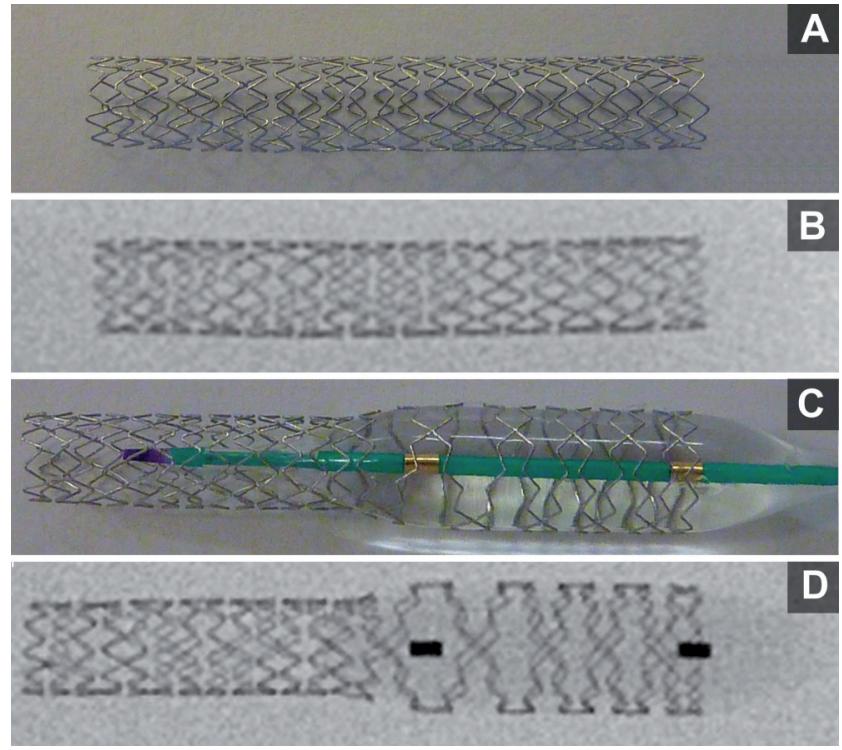

Figure 2. DES postdilatation (example of Endeavor Resolute stent): A) Photograph of DES after expansion at $14 \mathrm{~atm}$; B) High resolution radiographic image of $A ;$ C) Photograph of partial proximal postdilatation with $5 \mathrm{~mm}$ non-compliant balloon at $18 \mathrm{~atm}$; D) High resolution radiographic image of $\mathrm{C}$ (please note the large size of stent cells at the position of the distal balloon marker).

scanned stent samples, a copper filter was applied for optimal visualisation. Visual assessment of 3D-reconstruction of each DESsample was followed by a meticulous quantitative analysis.

The spaces between adjacent stent rings were numbered from proximal to distal. Links between adjacent stent rings (see above for details on links in description of DES samples) divided each space into two, three or seven stent cells. Stent diameters were measured at the middle of each space between adjacent stent rings. In addition, at each space between adjacent stent rings we measured the size of cell areas. To accurately measure the area of stent cells, cells were subdivided into small triangles and measurable quadrangles which allowed the measured areas to follow the spatial structure of the stents. The areas of these shapes were subsequently measured and added up to form the total area of a stent cell; five cell area measurements for each space between adjacent stent rings for each individual DES type were performed (a total of 330; 290 cells of postdilated stents and 40 cells of control stents). In addition, the distances between adjacent stent rings along each DES sample were measured, which permitted the quantification of longitudinal stent stretch in the transitional regions (expressed as percentage of between-ring distances in control samples).

\section{Data analysis and statistics}

Data are presented as a mean $\pm 1 S D$. Between DES comparison of the areas of corresponding stent cells was performed using the KuskalWallis test and Mann-Whitney test. While P-values <0.05 were generally considered significant, Bonferroni-Holm's correction was applied for multiple testing. Statistical analyses were performed with the software of SPSS version 15.0 (SPSS Inc., Chicago, IL, USA). 


\section{Results}

\section{Visual assessment of 3D-reconstructed Micro-CT image data}

In animated 3D-reconstructions of the DES samples (Figure 3, Videos 1-8), the closed cell-designed Cypher Select stent showed its largest cells in the postdilated stent region, while the other DES (with open-cell designs) showed the maximum cell areas in the transitional region just distal to the postdilated region (i.e., at the level of the distal marker of the postdilatation balloon; see Figure 2). The evaluation of cell size was even facilitated when DES were virtually sliced in a longitudinal direction to eliminate overlapping stent struts (panel A of Figures 4-7). In Cypher Select, Taxus Liberté, and Endeavor Resolute, the most proximal stent cells in the postdilated stent region were somewhat smaller than other cells in that region.

\section{Measurements of stent diameter}

Stent diameter of Cypher Select, Taxus Liberté, Endeavor Resolute, and Xience was in the control samples diameter values in controls $3.62 \pm 0.06 \mathrm{~mm}, 3.75 \pm 0.16 \mathrm{~mm}, 3.63 \pm 0.04 \mathrm{~mm}$, and $3.64 \pm 0.095 \mathrm{~mm}$, respectively. In the non-postdilated stent region (measured distal to the transitional region), the stent diameter measured $3.45 \pm 0.2 \mathrm{~mm}, 3.59 \pm 0.09 \mathrm{~mm}, 3.55 \pm 0.06 \mathrm{~mm}$, and $3.62 \pm 0.09 \mathrm{~mm}$, while in the postdilated region it measured $4.88 \pm 0.04 \mathrm{~mm}, 4.85 \pm 0.04 \mathrm{~mm}, 4.78 \pm 0.06 \mathrm{~mm}$, and $4.82 \pm 0.06 \mathrm{~mm}$, respectively (Figures $4-7$ ).

\section{Measurement of stent cell area}

The measured cell area $(n=40)$ in the control samples were: $3.48 \pm 0.29 \mathrm{~mm}^{2}, 3.62 \pm 0.14 \mathrm{~mm}^{2}, 6.49 \pm 0.25 \mathrm{~mm}^{2}, 4.83 \pm 0.26 \mathrm{~mm}^{2}$ for Cypher Select, Taxus Liberté, Endeavor Resolute, and Xience $\mathrm{V}$ respectively.
Measurements of 290 cell areas along the postdilated DES samples are presented in Figures 4-7. The maximum cell area (for all DES except for the Cypher Select stent being located in the transitional stent region) differed between DES types ( $p<0.001)$ : It was largest in Endeavor Resolute $\left(14.05 \pm 0.37 \mathrm{~mm}^{2} ; 216 \%\right.$ of the cell area of control sample; $\mathrm{p}<0.01)$; it was smallest in Cypher Select (3.48 $\pm 0.27 \mathrm{~mm}^{2} ; 140 \%$ of the cell area of control sample; $\left.p<0.01\right)$; both Xience V $\left(8.58 \pm 0.38 \mathrm{~mm}^{2} ; 183 \%\right.$ of the cell area of control sample) and Taxus Liberté $\left(6.34 \pm 0.11 \mathrm{~mm}^{2} ; 175 \%\right.$ of the cell area of control sample) showed an intermediate size.

Distances between adjacent rings of each stent were measured to examine the longitudinal expansion of stent cells, which was found to be greatest just distal to the postdilated region (transitional region where maximum cell areas were in open-cell design DES). At that site, the between-ring distance was significantly larger $(p<0.01)$ in Endeavor Resolute $3.33 \pm 0.07 \mathrm{~mm}(181 \pm 4 \%$ of the distance between adjacent stent rings in the control sample) compared to both, Xience $\vee 1.87 \pm 0.06 \mathrm{~mm}(166 \pm 5 \%)$ and Taxus Liberté $2.25 \pm 0.05 \mathrm{~mm}(165 \pm 3 \%)$. Only the postdilated Cypher Select did not demonstrate such a pattern. In all DES but the Xience $\mathrm{V}$, the smallest between-ring distance of the postdilated region was noticed in the most proximal postdilated region (Figures 4-7).

\section{Discussion}

\section{Rationale and design of the study}

Significant LM stenoses can be observed in 6-18\% of patients undergoing diagnostic coronary angiography ${ }^{14,15}$ and involves in two-thirds of these cases the distal LM stem. ${ }^{16}$ In the era of DES implantation, such lesions still carry a particularly high $\mathrm{PCl}$-risk (compared to lesions in the proximal or mid LM stems) ${ }^{17,18}$ as they require stenting of the transition between the distal LM stem and/or the proximal left anterior descending or circumflex artery with


Figure 3. Micro-CT 3D-image reconstruction of the four DES examined. 




Figure 4. Cypher Select. A) Micro-CT image of a virtually sliced DES with only slightly larger cells in the mid postdilated region. B) The horizontal axis represents the cell order from proximal to distal (e.g., cell one represents the most proximal cells, located in the space between the two most proximal stent rings). The upper curve represents area measurements of stent cells (see left vertical axis); the lower curve represents stent diameter (see right vertical axis) from the postdilated stent region (left) through the transitional region (mid) to the non-postdilated region (right).

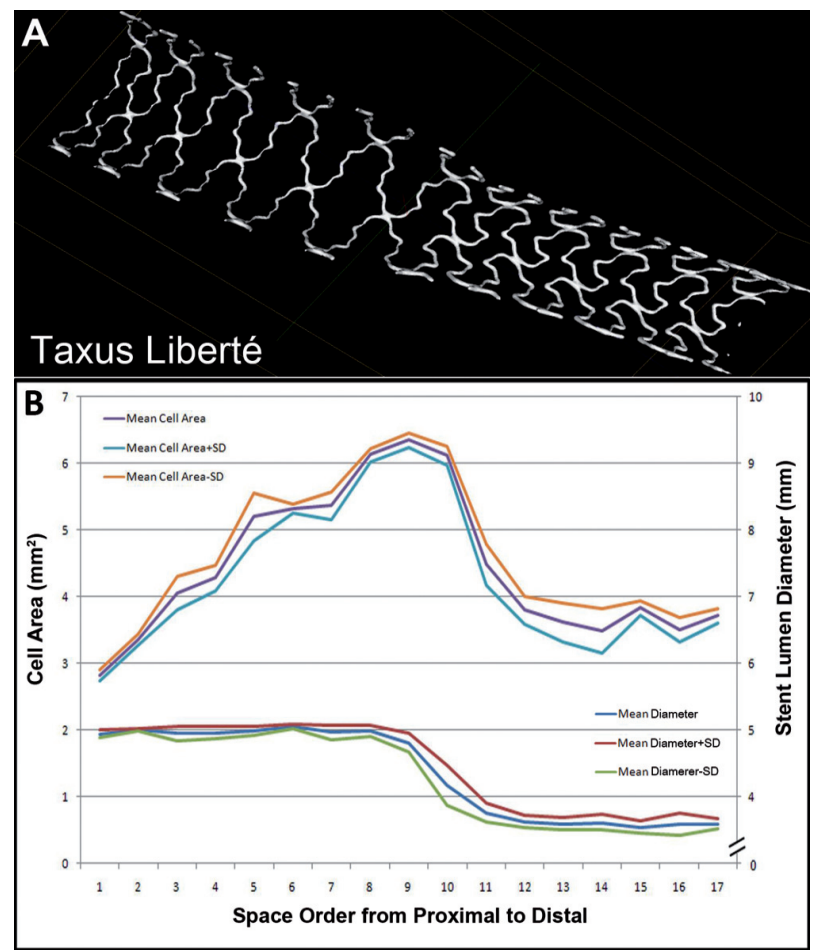

Figure 5. Taxus Liberté. A) Micro-CT image of a virtually sliced DES with larger cells in the transitional region. The cells in the most proximal part of the postdilated region (left hand side) are smaller. B) See legend to Figure 4.


Figure 6. Endeavor Resolute. A) Micro-CT image of a virtually sliced DES with increased cell size in transitional region and somewhat reduced cell size in the most proximal postdilated region. B) See legend to Figure 4.


Figure 7. Xience V. A) Micro-CT image of a virtually sliced DES with increased cell size in transitional region. B) See legend to Figure 4. 
inherent major vessel tapering (i.e., very substantial difference in vessel size between distal and proximal parts of the segment to be stented).

The size of the proximal left anterior descending or circumflex artery will generally limit the maximum nominal stent diameter that can be safely implanted without significant risk of dissection. This will usually lead to significant undersizing and malapposition of the DES in the distal LM stem which could (if not corrected) promote DES thrombosis. ${ }^{19}$ Therefore, significantly oversized postdilatation of the proximal part of the DES will usually be required. ${ }^{5-7}$ However, the consequences of this practice for DES geometry are greatly unknown and may differ between various DES types.

In the present study, DES with a nominal diameter of $3.5 \mathrm{~mm}$ were examined as this diameter corresponds well with the size of most proximal left anterior descending coronary arteries. All DES were first expanded at $14 \mathrm{~atm}$ as in previous bench side studies; ${ }^{20,21}$ the proximal part of all DES were then postdilated with a $5.0 \mathrm{~mm}$ noncompliant balloon to achieve approximately $130 \%$ stent overexpansion in diameter which corresponds well with usual left main stem dimensions. ${ }^{4}$

\section{Configuration of DES}

Visual assessment of coronary stent configuration has provided useful information on stent deformation in the context of bifurcation stenting. ${ }^{22-25}$ More recently, Ormiston et al performed bench side testing of the crush technique in DES with Micro-CT. ${ }^{26}$ Micro-CT is a precise imaging modality that permits high resolution, nondestructive imaging and 3D-reconstruction of spatial objects to be examined. ${ }^{27}$ The technique is very suitable to accurately measure small distances between stent struts. In this study, we used MicroCT to visualise the struts of the stent platforms of four DES types, while structural irregularities of DES coatings are better visualised by other techniques such as scanning electron microscopy (SEM). ${ }^{28}$ In our present bench side study, all four DES types showed an acute increase in cell area. In Taxus Liberté, Endeavor Resolute, and Xience $\mathrm{V}$, this increase was located in the transitional region (just distal to the postdilated region). Only Cypher Select showed its largest cell areas inside the postdilated stent region. Overall, the largest maximum cell area was observed in Endeavor Resolute while Cypher Select showed the smallest ( $p<0.001$, for both).

In this study, we were able to demonstrate the main mechanisms that led to this increase in stent cell area. Due to the difference in stent diameter between the postdilated and the non-postdilated region, stent cells in the transitional region were exposed to forces that led to both, (1) circumferential stent expansion (gradually decreasing from proximal to distal) and (2) longitudinal stent expansion (average stretch ranged from $165 \%$ to $181 \%$ for different open-cell DES). Differences in design and material of the bare metal platform may account for between DES differences in maximum cell area. For example, the closed cell design Cypher Select showed the smallest increase in the cell area and no longitudinal expansion between stent rings. In addition, it is very likely that stent material and design also account for the observed differences in spatial configuration of the proximal postdilated region. In fact, only Xience $\mathrm{V}$ showed a fairly invariable cell size along the postdilated region.
Mortier et al used Micro-CT data of various DES for the calculation of the maximum theoretically achievable stent cell area. ${ }^{9}$ In parallel with Mortier et al, we found the largest cell areas in Endeavor Resolute stents (DES based on Driver bare metal stent). In the present study, the measured maximum cell size differed between Taxus Liberté and Xience $V$, while according to calculations by Mortier et al (based on Micro-CT data), the maximally achievable stent cell area should be the same. ${ }^{9}$ Of note, the mechanisms that led to the maximum cell size (measured or presumed) differed between both studies (i.e., extremely oversized postdilatation of proximal part of DES only vs. postdilatation of stent cell with balloon catheter through stent struts). Therefore, both studies may be right; balloon dilatation through the struts of DES may thus result in similarly sized cells for Taxus Liberté and Xience V, however, after highly oversized partial postdilatation of DES (without balloon dilatation through stent struts), no such cell size was measured.

\section{Implications}

Between various DES types, there was a significant difference in the size of the largest stent cells that were for most DES types located in the transitional stent region (just distal to the postdilated region). This may be of practical interest in the context of distal LM stenting, as very large stent cells in DES provide better side branch access, but can be disadvantageous with regard to plaque scaffolding and prevention of recoil and restenosis. ${ }^{29}$ In the clinical setting, larger DES cells in the transitional region may be associated with less plaque coverage, which may have also consequences for drug distribution. Smaller stent cells - on the other hand - may provide better plaque scaffolding and prevention of recoil and restenosis while side branch access is often more difficult. An intermediate maximum cell size may represent a compromise between both extremes. The demands on a DES of choice for distal LM stenting may vary significantly between individual patients, depending on the specific lesion morphology and plaque distribution, and on side branch involvement with or without need for side branch access (e.g., in partially bypass-protected LM stems [see Figure 1] and in the presence of small or occluded LM side branches, access may not be required). As in the present bench side study, the maximum cell size differed between DES types, it may be allowed to hypothesize that there could be a difference between DES with regard to the necessity to perform final kissing balloon inflations following DES procedures in the distal LM stem.

Changes in stent length may also have clinical implications. Partial postdilatation of open-cell design stents in the current study resulted in DES elongation in the transitional stent region. In addition, most DES types demonstrated shortening of the most proximal part of the postdilated region. Changes in stent length could result in endothelial damage, however, in the clinical setting, the stent struts will be lodged in the arterial wall which could limit changes in stent length as observed in vitro.

\section{Limitations}

The present in vitro data should be interpreted cautiously as bench side studies cannot exactly mimic conditions in vivo. Nevertheless, we feel that meticulous Micro-CT examinations are important 
because they add valuable information to the overall picture of a DES, and may help to interpret clinical data. DES were not implanted in standard vascular phantoms as they could have limited significant partial DES oversizing, which was critically important for this study protocol. The consequences of simultaneous (kissing) balloon inflations on DES geometry were not addressed in the present study but may be subject of further research. However, as two-balloon approaches are inevitably associated with some oversized partial DES postdilatation, our present study addresses a major component of the optimisation process of stents implanted along major coronary bifurcations.

\section{Conclusions}

In four commercially available DES, extremely oversized postdilatation of the proximal stent region demonstrated significant differences in final spatial configuration and maximum cell size, which was found inside the postdilated stent region of a closed-cell DES and just distal to the postdilated region in various open-cell design DES. The findings of this bench side study could be of practical interest in the context of left main interventions with stenting across the left main bifurcation, where the choice of DES may depend upon lesion morphology, plaque distribution, side branch involvement, and the need for side branch access.

\section{Acknowledgements}

The research department of Thoraxcentrum Enschede has received in the past unrestricted research grants and/or has participated in clinical studies funded by Abbott Vascular, Biosensors International, Biotronik, Boston Scientific, Cordis Corporation, and Medtronic.

Funding and support: Free DES samples were provided by Abbott Vascular, Boston Scientific, and Medtronic; no financial support was obtained; this study was investigator-initiated.

\section{References}

1. Serruys PW, Morice MC, Kappetein AP, Colombo A, Holmes DR, Mack MJ, Stahle E, Feldman TE, van den Brand M, Bass EJ, Van Dyck N, Leadley K, Dawkins KD, Mohr FW. Percutaneous coronary intervention versus coronary-artery bypass grafting for severe coronary artery disease. N Engl J Med 2009;360:961-972.

2. Buszman PE, Buszman PP, Kiesz RS, Bochenek A, Trela B, Konkolewska M, Wallace-Bradley D, Wilczynski M, BanasiewiczSzkrobka I, Peszek-Przybyla E, Krol M, Kondys M, Milewski K, Wiernek S, Debinski M, Zurakowski A, Martin JL, Tendera M. Early and long-term results of unprotected left main coronary artery stenting: the LE MANS (Left Main Coronary Artery Stenting) registry. J Am Coll Cardiol 2009;54:1500-1511.

3. Kandzari DE, Colombo A, Park SJ, Tommaso CL, Ellis SG, Guzman LA, Teirstein PS, Tamburino C, Ormiston J, Stone GW, Dangas GD, Popma JJ, Bass TA. Revascularization for unprotected left main disease: evolution of the evidence basis to redefine treatment standards. J Am Coll Cardiol 2009;54:1576-1588.

4. Ge J, Erbel R, Gerber T, Gorge G, Koch L, Haude M, Meyer J. Intravascular ultrasound imaging of angiographically normal coronary arteries: a prospective study in vivo. British Medical Journal 1994;71:572-578.
5. Fujii K, Carlier SG, Mintz GS, Yang YM, Moussa I, Weisz G, Dangas G, Mehran R, Lansky AJ, Kreps EM, Collins M, Stone GW, Moses JW, Leon MB. Stent underexpansion and residual reference segment stenosis are related to stent thrombosis after sirolimus-eluting stent implantation: an intravascular ultrasound study. J Am Coll Cardiol 2005;45:995-998.

6. Alfonso F, Suarez A, Perez-Vizcayno MJ, Moreno R, Escaned J, Banuelos C, Jimenez P, Bernardo E, Angiolillo DJ, Hernandez R, Macaya C. Intravascular ultrasound findings during episodes of drug-eluting stent thrombosis. J Am Coll Cardiol 2007;50:2095-2097.

7. Cook S, Wenaweser P, Togni M, Billinger M, Morger C, Seiler $C$, Vogel R, Hess O, Meier B, Windecker S. Incomplete stent apposition and very late stent thrombosis after drug-eluting stent implantation. Circulation 2007; 115:2426-2434

8. Price MJ, Cristea E, Sawhney N, Kao JA, Moses JW, Leon MB, Costa RA, Lansky AJ, Teirstein PS. Serial angiographic follow-up of sirolimus-eluting stents for unprotected left main coronary artery revascularization. J Am Coll Cardiol 2006;47:871-877.

9. Mortier P, Van Loo D, De Beule M, Segers P, Taeymans Y, Verdonck P, Verhegghe $\mathrm{B}$. Comparison of drug-eluting stent cell size using micro-CT: important data for bifurcation stent selection. Eurolntervention 2008;4:391- 396

10. Serruys PW, Regar E, Carter AJ. Rapamycin eluting stent: the onset of a new era in interventional cardiology. Heart 2002;87:305-307.

11. FDA Summary of Safety and Effectiveness Data of Taxus Liberté. 2008. Report No.: P060008.

12. Meredith IT, Worthley S, Whitbourn R, Walters D, Popma J, Cutlip D, Fitzgerald P. The next-generation Endeavor Resolute stent: 4-month clinical and angiographic results from the Resolute first-in-man trial. Eurolntervention 2007;3:50-53.

13. Stone GW, Midei M, Newman W, Sanz M, Hermiller JB, Williams J, Farhat N, Mahaffey KW, Cutlip DE, Fitzgerald PJ, Sood P, Su X, Lansky AJ. Comparison of an everolimus-eluting stent and a paclitaxel-eluting stent in patients with coronary artery disease: a randomized trial. JAMA 2008;299:1903-1913.

14. Proudfit WL, Shirey EK, Sones FM, Jr. Distribution of arterial lesions demonstrated by selective cinecoronary arteriography. Circulation 1967;36:54-62.

15. Sukhija R, Yalamanchili K, Aronow WS. Prevalence of left main coronary artery disease, of three- or four-vessel coronary artery disease, and of obstructive coronary artery disease in patients with and without peripheral arterial disease undergoing coronary angiography for suspected coronary artery disease. Am J Cardiol 2003;92:304-305.

16. Cameron A, Kemp HG, Fisher LD, Gosselin A, Judkins MP, Kennedy JW, Lesperance J, Mudd JG, Ryan TJ, Silverman JF. Left main coronary artery stenosis: angiographic determination. Circulation 1983;68:484-489

17. Valgimigli M, Malagutti $P$, Aoki J, Garcia-Garcia HM, Rodriguez Granillo GA, van Mieghem CA, Ligthart JM, Ong AT, Sianos G, Regar E, Van Domburg RT, De FP, de JP, Serruys PW. Sirolimus-eluting versus paclitaxel-eluting stent implantation for the percutaneous treatment of left main coronary artery disease: a combined RESEARCH and T-SEARCH long-term analysis. J Am Coll Cardiol 2006;47:507-514.

18. Chen SL, Ye F, Zhang JJ, Liu ZZ, Lin S, Zhu ZS, Sun XW, Li F, Zhang AP, Chen JG, Ji QJ, Qian J, Chen F, Kwan TW. Distal left main coronary bifurcation lesions predict worse outcome in patients undergoing percutaneous implantation of drug-eluting stents: results from the Drug-Eluting Stent for the Treatment of Left Main Disease (DISTAL) Study. Cardiology 2009;113:264-273. 
19. Ramcharitar S, Ligthart J, van der Giessen WJ. Stent undersizing can result in procedure-related very late stent thrombosis. J Invasive Cardiol 2007;19:E276-E277.

20. Basalus MW, van Houwelingen KG, Ankone M, de Man FH, von Birgelen C. Scanning electron microscopic assessment of the biodegradable coating on expanded biolimus-eluting stents. Eurolntervention 2009;5:505-510.

21. Basalus MW, Ankone MJ, van Houwelingen GK, de Man FH, von Birgelen C. Coating irregularities of durable polymer-based drug-eluting stents as assessed by scanning electron microscopy. Eurolntervention 2009;5:157-165.

22. Ormiston JA, Webster MW, Ruygrok PN, Stewart JT, White HD, Scott DS. Stent deformation following simulated side-branch dilatation: a comparison of five stent designs. Catheter Cardiovasc Interv 1999;47:258-264.

23. Ormiston JA, Currie E, Webster MW, Kay P, Ruygrok PN, Stewart JT, Padgett RC, Panther MJ. Drug-eluting stents for coronary bifurcations: insights into the crush technique. Catheter Cardiovasc Interv 2004;63:332-336.
24. Ormiston JA, Webster MW, El JS, Ruygrok PN, Stewart JT, Scott D, Currie E, Panther MJ, Shaw B, O'Shaughnessy B. Drug-eluting stents for coronary bifurcations: bench testing of provisional side-branch strategies. Catheter Cardiovasc Interv 2006;67:49-55.

25. Carrie D, Karouny E, Chouairi S, Puel J. "T"-shaped stent placement: a technique for the treatment of dissected bifurcation lesions. Cathet Cardiovasc Diagn 1996;37:311-313.

26. Ormiston JA, Webster MWI, Webber B, Stewart JT, Ruygrok PN, Hatrick RI. The (crush) technique for coronary artery bifurcation stenting: insights from micro-computed tomographic imaging of bench deployments. JACC: Cardiovascular Interventions 2008;1:351-357.

27. Ritman EL. Micro-computed tomography-current status and developments. Annu Rev Biomed Eng 2004;6:185-208.

28. Basalus MW, von Birgelen C. Benchside testing of drug-eluting stent surface and geometry. Interventional Cardiology 2010;2:159-175.

29. Ako J, Bonneau HN, Honda Y, Fitzgerald PJ. Design criteria for the ideal drug-eluting stent. Am J Cardiol 2007;100:3M-9M. 